\title{
Investigation of structural, thermal and dielectric properties of PVC/modified magnetic nanoparticle composites
}

\author{
Abdulrahman TUKUR ${ }^{1 \text { (D) }, \text { Mustafa Ersin PEKDEMIR }}{ }^{1 *}$ (D), Mehmet ÇOŞKUN ${ }^{1}$ (D) \\ ${ }^{1}$ Firat University, Chemistry Departmenty, 23119, Elazığ/TURKEY
}

\begin{abstract}
Three different composites $(5,10$, and $20 \mathrm{wt}$. \%) were prepared using purified $\mathrm{PVC}$ and $\mathrm{POH}-$ $g$ - $\mathrm{N}_{3} \mathrm{PTMS}-\mathrm{g}-\mathrm{Fe}_{3} \mathrm{O}_{4}$. Firstly, 3-azidopropyltrimethoxysilane was synthesized under reflux from 3-chlorotrimethoxysilane and sodium azide. Then, magnetic nanoparticle was bonded with the silane group of 3-azidopropyltrimethoxysilane. After that the 3azidopropyltrimethoxysilane bearing magnetic nanoparticle undergo click reaction with propargyl alcohol, and then the composites were prepared. Some characterization, including FT-IR spectroscopy, SEM, Differential scanning calorimetry (DSC), vibrating sample magnetometer (VSM), and EDX images was performed to the composites. The DSC measurements showed that the click reaction of the 3-azidopropyltrimethoxysilane graft magnetic nanoparticles $\left(\mathrm{N}_{3}\right.$ PTMS- $g$ - $\left.\mathrm{Fe}_{3} \mathrm{O}_{4}\right)$ reduced the glass transition temperature $\left(T_{g}\right)$. Click reaction reduced the thermal stability of $\mathrm{N}_{3} \mathrm{PTMS}-\mathrm{g}-\mathrm{Fe}_{3} \mathrm{O}_{4}$. The thermal stabilities of the composites increased by increasing the compositional rate. It was found that the 10\% PVC $/ \mathrm{POH}-g-\mathrm{N}_{3} \mathrm{PTMS}-\mathrm{g}-\mathrm{Fe}_{3} \mathrm{O}_{4}$ reached saturation magnetization $\left(M_{s}\right)$ at $5.12 \mathrm{emu} / \mathrm{g}$. The dielectric constant $\left(\varepsilon^{\prime}\right)$ and dielectric loss $\left(\varepsilon^{\prime \prime}\right)$ of POH- $g-\mathrm{N}_{3}$ PTMS- $g$ - $\mathrm{Fe}_{3} \mathrm{O}_{4}$ rapidly decreased with increasing applied frequency and then remain more or less constant. Also, the AC conductivity $\left(\sigma_{a c}\right)$ increased sharply with increasing the applied frequency. While the $\varepsilon^{\prime}$ decreased slightly for the composites by increasing the applied frequency and the $\sigma_{a c}$ increase dramatically with an increase in applied frequency at room temperature.
\end{abstract}

\author{
Article info \\ History: \\ Received:07.04.2020 \\ Accepted:04.06.2020 \\ Keywords: \\ $\mathrm{PVC}$, \\ $\mathrm{Fe}_{3} \mathrm{O}_{4}$ nanoparticles, \\ Click reaction, \\ Composite, \\ Dielectric.
}

\section{Introduction}

The unique electrical, thermal, optical, electronic, and mechanical characteristics properties of metal nanoparticles and nanocomposites make them the subject of extensive researches. Polymers, as ideal host matrices, are good candidates for composite materials [1]. Materials having magnetic properties are of great interest to many possible applications. Amid the number of magnetic nanomaterials, $\mathrm{Fe}_{3} \mathrm{O}_{4}$ nanoparticles attracted far attention owed to their unique properties [2]. Recently, inorganic-polymer composite has been studied deeply due to their specific use and properties [3], e.g., magnetite/polymer nanocomposite is one of the attractive nanocomposites [4]. Due to its wide applications, poly(vinyl chloride) (PVC) is picked as the host polymer matrix. $\mathrm{PVC}$ is a polymer that has lots of characteristics suitable for industrial applications, such as good mechanical properties, good processability, fire retardancy, and good resistance to acidic and basic environments.
Additionaly, PVC has a desirable properties, including low cost of production, biocompatibility, and chemical stability [5]. PVC thermal and mechanical properties can be improved by additives addition such as clay, wood fibers and flour, and calcium carbonate [5]. The electrical properties of PVC can be enhanced through incorporating zinc oxide nanorods [6], conjugated polymers (such as polyaniline and polypyrrole) [7], $\mathrm{SiO}_{2}$ nanoparticle [8], and carbon black [9] enbeded in the PVC matrix. The simultaneous presence of $\mathrm{Fe}_{3} \mathrm{O}_{4}$ nanoparticles, and graphene serve as a nanofiller in the PVC matrix which increases the young's modulus, tensile strength, and conductivity compared to that of pure PVC [10]. These improvements are linked to the synergistic effect of the host polymer and nanometer dimensional dispersion of inorganic nanoparticles. Furthermore, thermal stability studies and dielectric properties of various important polymers and their composites have been studied. Magnetic nanoparticles bonded to PVC with the help of click reaction showed an increase in thermal stability and dielectric constant compared to pure PVC. The saturation magnetization 
value revealed that the product is a superparamagnetic [11]. Magnetic nanocomposite prepared by $\mathrm{Fe}_{3} \mathrm{O}_{4}$ nanoparticles and polystyrene can be used for microelectromechanical systems, since it shows good electrical conductivity [3]. The influence of magnetic nanoparticles was studied for chitin/cashew biopolymer composites, and the results revealed that an increase in thermal stability and the dielectric properties was improved due to the interaction with $\mathrm{Fe}_{3} \mathrm{O}_{4}$ nanoparticles [12]. Likewise, $\mathrm{Fe}_{3} \mathrm{O}_{4}$ nanoparticles/polymer composite was studied for polyvinyl butyral/magnetite $\left(\mathrm{PVB} / \mathrm{Fe}_{3} \mathrm{O}_{4}\right)$ and polymethylmethacrylate/magnetite $\quad\left(\mathrm{PMMA} / \mathrm{Fe}_{3} \mathrm{O}_{4}\right)$ composites [13], pectin-magnetite nanocomposite [14], superparamagnetic iron oxide nanoparticles, graphene oxide, chitosan, and poly(vinyl alcohol) biocompatible polymers [15].

In this study, the 3-chloropropyltrimethoxysilane was reacted with sodium azide in the presence of tetraethylammonium bromide to form 3azidopropyltrimethoxysilane. This is bounded to $\mathrm{Fe}_{3} \mathrm{O}_{4}$ nanoparticles. The modified magnetic nanoparticle formed undergoes click reaction with propargyl alcohol to form $\mathrm{Fe}_{3} \mathrm{O}_{4}$ nanoparticles bearing 1,2,3triazole ring and then, three composites of $\mathrm{PVC}$ were prepared by embeding the modified $\mathrm{Fe}_{3} \mathrm{O}_{4}$ nanoparticles with various concentrations. FT-IR spectroscopy and SEM/EDX were used for structural characterization. DSC and TGA techniques were used for glass transition temperature and thermal stability of the composites. The magnetic property of $10 \%$ composite was investigated using vibrating sample magnetometry (VSM). And lastly, dielectric and AC conductivity properties of the modified $\mathrm{Fe}_{3} \mathrm{O}_{4}$ nanoparticles and composites were studied.

\section{Materials and Methods}

\subsection{Apparatus}

T Perkin-Elmer Spectrum one FT-IR spectrometer was used to record Infrared spectra. Morphology studies were performed with the Zeis EVO MA10 scanning electron microscope (SEM). Calorimetric measurements were accomplished using PerkinElmer instruments Sapphire DSC at a heating rate of 20 ${ }^{\circ} \mathrm{C} / \mathrm{min}$ under $\mathrm{N}_{2}$ flow. Thermal stability were recorded using PerkinElmer instruments Pyris Diamond TGA under $\mathrm{N}_{2}$ flow at a heating rate of $10{ }^{\circ} \mathrm{C} / \mathrm{min}$. Dielectric measurements were carried out using QuadTech 7600 precision LCR meter. Magnetic properties was investigated using Quantum Design PPMS-9T.

\subsection{Synthesis of 3-azidopropyltrimethoxysilane (N3PTMS)}

$\mathrm{NaN}_{3} \quad(2.14 \quad \mathrm{~g}, \quad 33.2 \quad \mathrm{mmol}), \quad 3-$ chloropropyltrimethoxysilane (ClTMS) (3.30 g, 16.6 $\mathrm{mmol}$ ), and tetraethylammonium bromide (TEABr) ( $0.84 \mathrm{~g}, 4 \mathrm{mmol})$ were passed into a single neck round bottom flask stocked with reflux condenser containing $50 \mathrm{~mL}$ acetonitrile, under argon atmosphere. The reaction continued under reflux for $18 \mathrm{~h}$. The solvent was evaporated after completion, the crude like mixture acquired was diluted in dry hexane and filtered. The solvent was evaporated and the colorless liquid formed is 3-azidopropyltrimethoxysilane [16].

\subsection{Bonding of magnetic nanoparticle $\left(\mathrm{Fe}_{3} \mathrm{O}_{4}\right)$ to 3-} azidopropyltrimethoxysilane ( $\mathbf{N}_{3}$ PTMS)

$\mathrm{Fe}_{3} \mathrm{O}_{4}$ nanoparticles $(2.00 \mathrm{~g}$ ) was homogenized for 30 min in $75 \mathrm{~mL}$ absolute ethanol. $\mathrm{N}_{3}$ PTMS (2.00 g) was added and Argon was injected for about $15 \mathrm{~min}$, and the process continued at ambient temperature for $6 \mathrm{~h}$, then under reflux for $48 \mathrm{~h}$. $\mathrm{Fe}_{3} \mathrm{O}_{4}-g-\mathrm{N}_{3}$ PTMS was separated magnetically, then washed with alcohol, and dried at room temperature followed by vacuum for 24 $h$ at $50^{\circ} \mathrm{C}$.

\subsection{Click reaction of $\mathrm{N}_{3} \mathrm{PTMS}-g-\mathrm{Fe}_{3} \mathrm{O}_{4}$ and propargyl alcohol ( $\mathrm{POH})$}

In a flask, $\mathrm{N}_{3} \mathrm{PTMS} \mathrm{g}-\mathrm{Fe}_{3} \mathrm{O}_{4} \quad\left(\begin{array}{lll}1.00 & \mathrm{~g}\end{array}\right)$ was homogenized for $30 \mathrm{~min}$ in $15 \mathrm{~mL}$ dimethylformamide (DMF). Then propargyl alcohol (POH) $(1.33 \mathrm{~g})$ was added to the solution. After that $\mathrm{Cu}(\mathrm{I}) \mathrm{Br} 0.07 \mathrm{~g}(0.48$ $\mathrm{mmol})$ and 5,5'-dimethyl-2,2'-dipyridyl $0.22 \mathrm{~g}$ (0.48 mmol) were dissolved in $5 \mathrm{~mL}$ DMF in a beaker and poured to the previous solution. Argon was passed for $15 \mathrm{~min}$ and continued at $30^{\circ} \mathrm{C}$ for $24 \mathrm{~h}$. The product was washed under a magnet with dichloromethane and dried at room temperature for $24 \mathrm{~h}$ followed by vacuum at $50{ }^{\circ} \mathrm{C}$ for $24 \mathrm{~h}$.

\subsection{Preparation of composite of PVC with POH-g- $\mathrm{N}_{3}$ PTMS- $g-\mathrm{Fe}_{3} \mathrm{O}_{4}$}

Firstly, $10 \mathrm{~mL}$ tetrahydrofuran (THF) was used to dissolve PVC $(0.50 \mathrm{~g})$. 5\% (0.025 g) POH- $\mathrm{N}_{3}$ PTMS- $g-\mathrm{Fe}_{3} \mathrm{O}_{4}$ was added to the mixture and sonicated for $45 \mathrm{~min}$. The solution was precipitated in ethanol, filtered, dried at room temperature, and then vacuum for $24 \mathrm{~h}$ at $45^{\circ} \mathrm{C}$. The procedure abovementioned was used to prepare $10 \% \quad(0.05 \mathrm{~g})$ and $20 \% \quad(0.10 \mathrm{~g})$ composites.

\section{Results and Discussion}

\subsection{FTIR and SEM characterization}


3-azidopropyltrimethoxysilane was formed by a nucleophilic substitution reaction of 3-

chloropropyltrimethoxy -silane and sodium azide (Scheme 1).

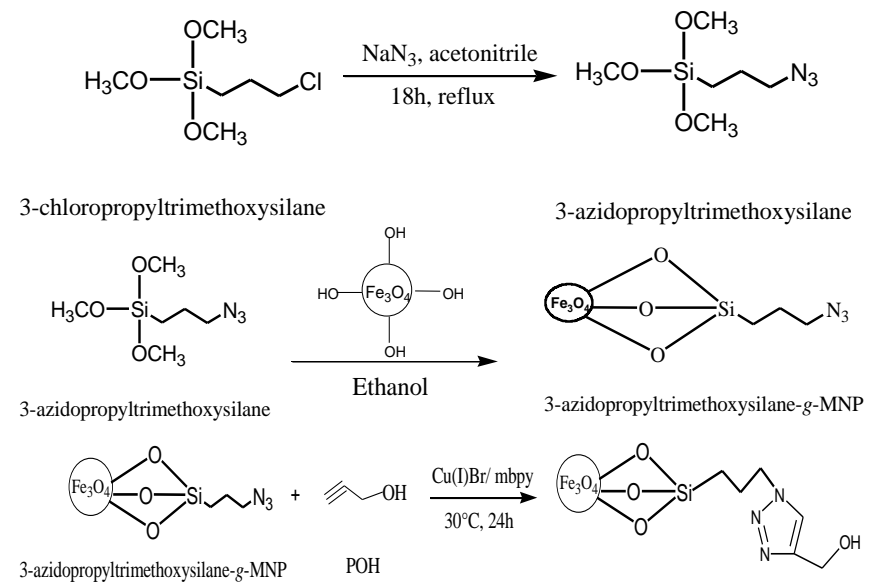

Scheme 1. Reaction pathways in the synthesis of $\mathrm{POH}-\mathrm{g}$ $\mathrm{N}_{3}$ PTMS- $g-\mathrm{Fe}_{3} \mathrm{O}_{4}$

The FT-IR spectrum of 3azidopropyltrimethoxysilane (Figure 1a) shows an absorption band at $2101 \mathrm{~cm}^{-1}$ which is distinctive and characteristic stretching vibration for $-\mathrm{N}$ $\mathrm{N} \equiv \mathrm{N}$ group. The signal confirms the formation of 3-azidopropyltrimethoxysilane. Other absorption bands are 2843-2944 $\mathrm{cm}^{-1}$ (C-H stretching from aliphatic $\left.-\mathrm{CH}_{2}\right)$ and $1087 \mathrm{~cm}^{-1}$ (Si-O). The FT-IR spectrum (Figure 1b) of $\mathrm{N}_{3} \mathrm{PTMS}-\mathrm{g}-\mathrm{Fe}_{3} \mathrm{O}_{4}$ formed by grafting of $\mathrm{Fe}_{3} \mathrm{O}_{4}$ to 3azidopropyltrimethoxysilane shows the characteristic band at $586 \mathrm{~cm}^{-1}(\mathrm{Fe}-\mathrm{O}$ which indicates the bonding of $\left.\mathrm{Fe}_{3} \mathrm{O}_{4}\right)$ and $3435 \mathrm{~cm}^{-1}(\mathrm{O}-$ $\mathrm{H}$ stretch from $\mathrm{Fe}_{3} \mathrm{O}_{4}$ particle surface). 2923 and $2099 \mathrm{~cm}^{-1}$ bands are for aliphatic C-H and $-\mathrm{N}$ $\mathrm{N} \equiv \mathrm{N}$ stretching vibrations respectively. The product carrying $\mathrm{Fe}_{3} \mathrm{O}_{4}$ undergoes click reaction with propargyl alcohol (Scheme 1). The FT-IR spectrum (Figure 1c) shows the bands formed from the product of click reaction. 1598 and 1467 $\mathrm{cm}^{-1}$ represent absorption bands respectively for $\mathrm{C}=\mathrm{C}$ and $\mathrm{C}-\mathrm{N}$ stretching vibrations from the 1,2,3triazole ring.

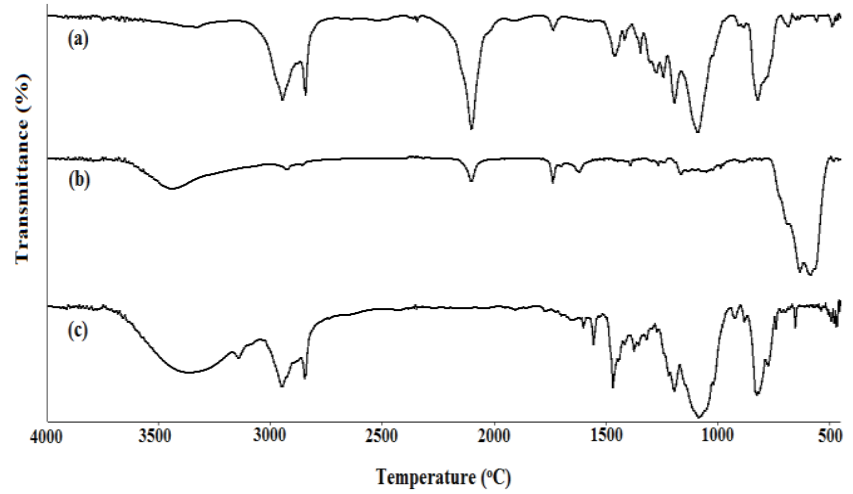

Figure 1. FT-IR spectra of (a) $\mathrm{N}_{3}$ PTMS (b) N $\mathrm{N}_{3}$ PTMS- $g$ $\mathrm{Fe}_{3} \mathrm{O}_{4}$ and (c) POH- $g-\mathrm{N}_{3}$ PTMS- $g$ - $\mathrm{Fe}_{3} \mathrm{O}_{4}$

Figure $2 \mathrm{a}$ and Figure $3 \mathrm{a}$ depict (SEM) images of $\mathrm{N}_{3}$ PTMS- $g-\mathrm{Fe}_{3} \mathrm{O}_{4}$ and POH-N $\mathrm{N}_{3}$ PTMS- $g$ - $-\mathrm{Fe}_{3} \mathrm{O}_{4}$ respectively. The surface morphology of the modified magnetic nanoparticle and composites was examined at 10,000 magnification. It can be deduced that the $\mathrm{Fe}_{3} \mathrm{O}_{4}$ magnetic nanoparticle (Figure 2a) dominate in the sample and shows good uniformity. After click reaction with propargyl alcohol, the cubic structure of $\mathrm{Fe}_{3} \mathrm{O}_{4}$ magnetic nanoparticle (Figure 3a) becomes more prominent due to the formation of the 1,2,3triazole ring. The compositional ratio and the type of constituents was determined using the EDX analysis for the samples shown in Figure $2 \mathrm{~b}$ and $3 \mathrm{~b}$. Fe, C, O, $\mathrm{N}, \mathrm{Si}$, and $\mathrm{Cl}$ are present in both the samples with different percentages. SEM images of 5 and $20 \% \mathrm{POH}-$ $\mathrm{N}_{3}$ PTMS- $g$ - $\mathrm{Fe}_{3} \mathrm{O}_{4} / \mathrm{PVC}$ composite are respectively depicted in Figures 4a and Figure 5a. The composite showed that most of the POH-N $\mathrm{N}_{3} \mathrm{PTMS}-\mathrm{g}-\mathrm{Fe}_{3} \mathrm{O}_{4}$ are dispersed well within the PVC matrix with good uniformity and minor irregularities that are more visible on a $20 \%$ composite image at the lower part of the sample which is probably due to higher concentration of POH-N 3 PTMS- $g-\mathrm{Fe}_{3} \mathrm{O}_{4}$ in the composite. EDX image in Figures $4 \mathrm{~b}$ and Figure $5 \mathrm{~b}$ reveal the presence of $\mathrm{Fe}, \mathrm{C}, \mathrm{Cl}, \mathrm{O}, \mathrm{N}$, and $\mathrm{Si}$ in both composite samples. 


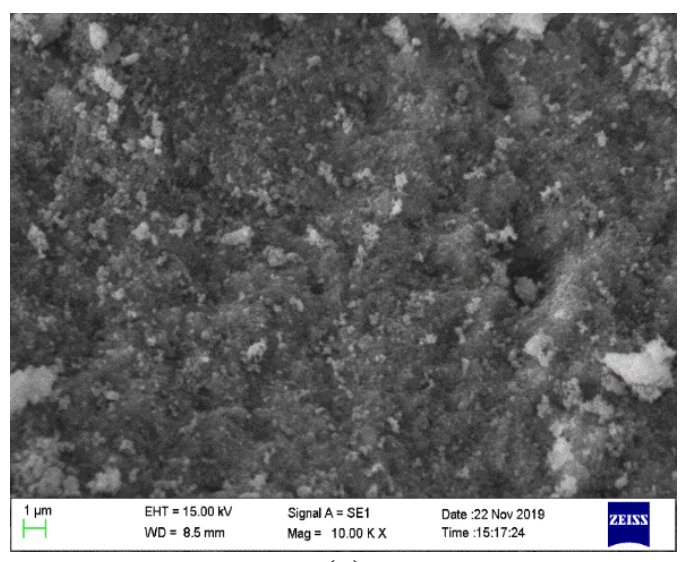

(a)

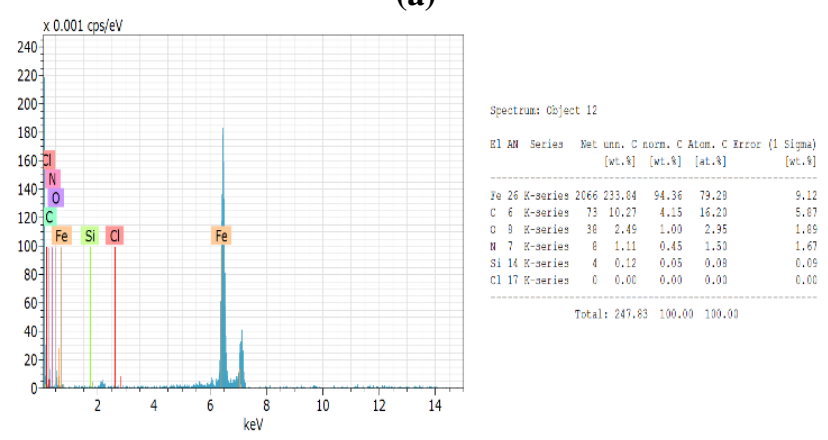

(b)

Figure 2. (a) SEM and (b) EDX images of $\mathrm{N}_{3}$ PTMS-g$\mathrm{Fe}_{3} \mathrm{O}_{4}$

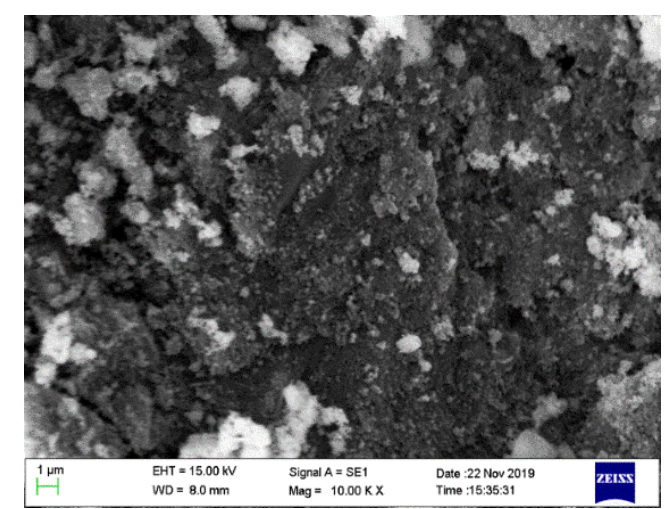

(a)

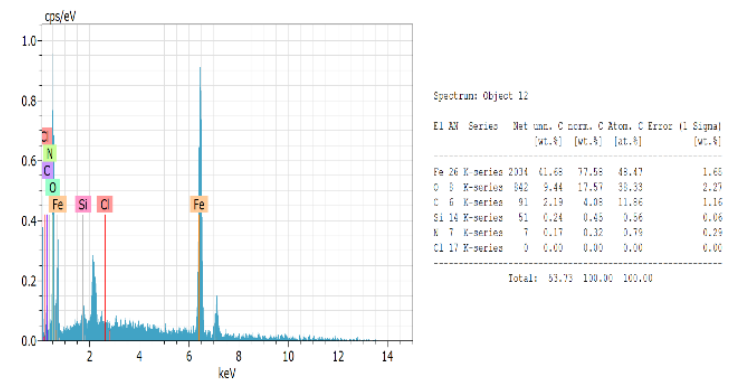

(b)

Figure 3. (a) SEM and (b) EDX images of POH- $g$ - $\mathrm{N}_{3} \mathrm{PTMS}$ $g-\mathrm{Fe}_{3} \mathrm{O}_{4}$

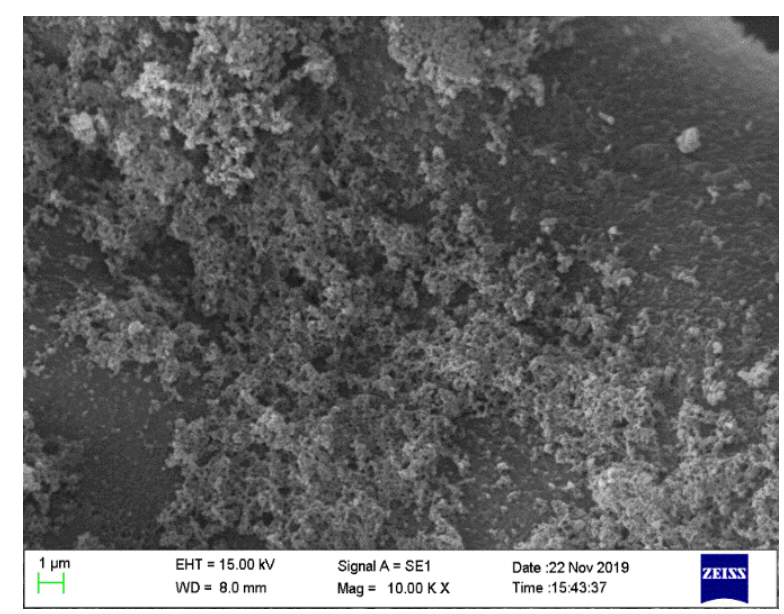

(a)

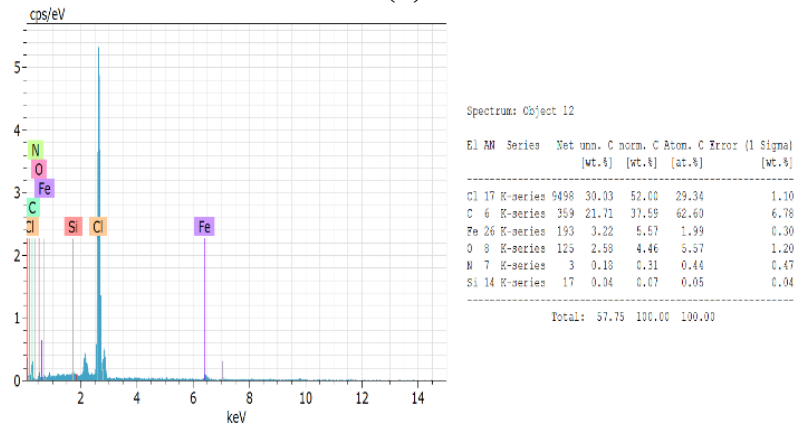

(b)

Figure 4. (a) SEM and (b) EDX images of PVC / $5 \%$ POH$\mathrm{N}_{3}$ PTMS- $g-\mathrm{Fe}_{3} \mathrm{O}_{4}$ composite

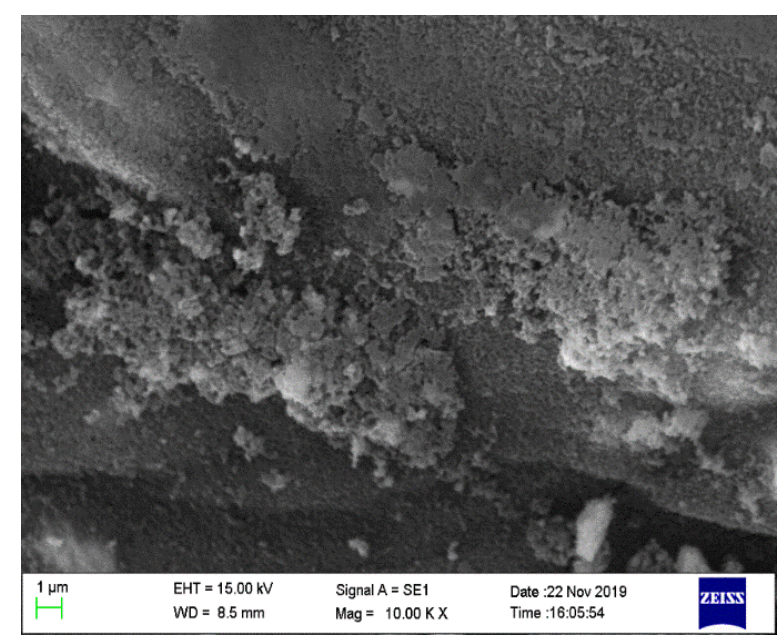

(a)

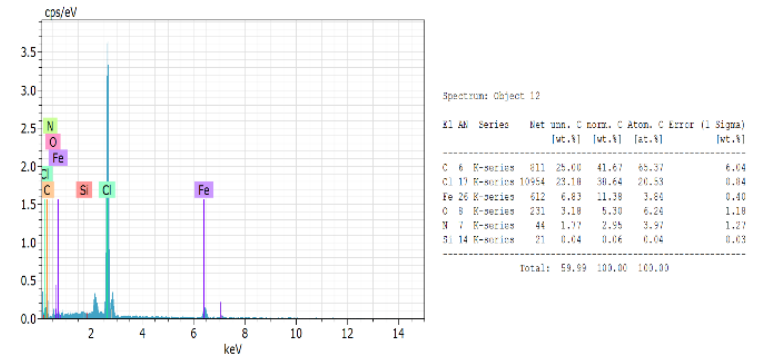

(b)

Figure 5. (a) SEM and (b) EDX images of PVC / $20 \% \mathrm{POH}-$ $\mathrm{N}_{3}$ PTMS- $g$ - $-\mathrm{Fe}_{3} \mathrm{O}_{4}$ composite 


\subsection{Magnetic investigation}

The magnetic property of PVC/10\% POH-N 3 TMS- $g$ $\mathrm{Fe}_{3} \mathrm{O}_{4}$ composite was studied using a vibrating sample magnetometer (VSM) at 300K. From Figure 6, it can be seen that the magnetization curve has s-shaped over the applied magnetic field and the sample, $10 \%$ PVC$g$-POH-N ${ }_{3}$ TMS- $g$ - $\mathrm{Fe}_{3} \mathrm{O}_{4}$ composite showed saturation magnetization $\left(M_{s}\right)$ around $5.12 \mathrm{emu} / \mathrm{g}$ which is far lower than $M_{s}$ values of pure $\mathrm{Fe}_{3} \mathrm{O}_{4}$ nanoparticle reported in literature. The $\mathrm{Fe}_{3} \mathrm{O}_{4}$ nanoparticle bonded to PVC with the help of click reaction showed $M_{s}$ of $41.5 \mathrm{emu} / \mathrm{g}$ [11]. The $M_{s}$ value from the VSM plot is essential evidence of the presence of $\mathrm{Fe}_{3} \mathrm{O}_{4}$ magnetic nanoparticles within the composite.

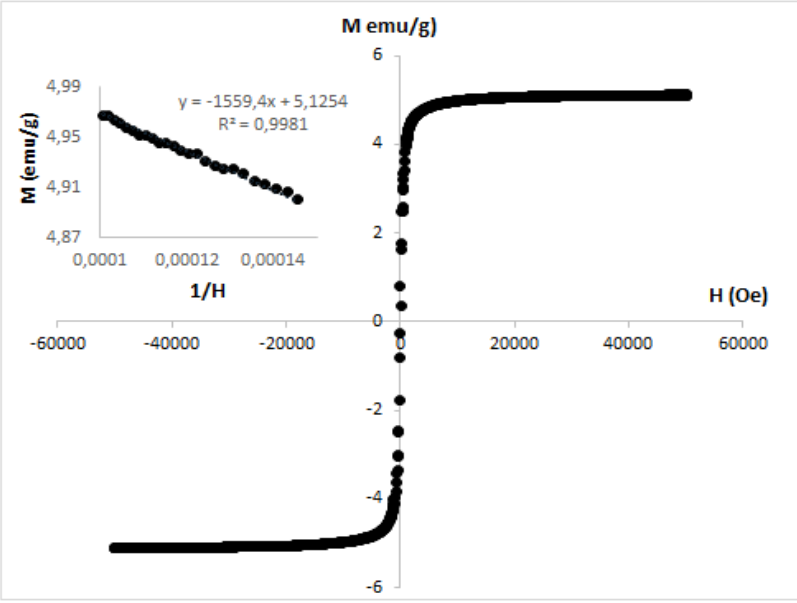

Figure 6. VSM plot of $10 \%$ PVC / POH- $g-\mathrm{N}_{3}$ PTMS- $g$ $\mathrm{Fe}_{3} \mathrm{O}_{4}$ composite

\subsection{Thermal investigation}

DSC curves of $\mathrm{N}_{3}$ PTMS- $g$ - $\mathrm{Fe}_{3} \mathrm{O}_{4}$ and POH-N ${ }_{3}$ PTMS$g-\mathrm{Fe}_{3} \mathrm{O}_{4}$ are depicted in Figure 7. The glass transition temperatures $\left(T_{g}\right)$ determined based on the intermediate of the glass transition region and listed in Table 1 . The $T_{g}$ of $61{ }^{\circ} \mathrm{C}$ was recorded before click reaction with propargyl alcohol and the $T_{g}$ of $57^{\circ} \mathrm{C}$ was recorded after click reaction. The $T_{g}$ was decreased by increasing the chain flexibility of the $\mathrm{POH}-\mathrm{N}_{3}$ PTMS$g-\mathrm{Fe}_{3} \mathrm{O}_{4}$ as a result of click reaction. TGA curves of $\mathrm{N}_{3}$ PTMS- $g-\mathrm{Fe}_{3} \mathrm{O}_{4}$ and POH-N ${ }_{3}$ PTMS- $g-\mathrm{Fe}_{3} \mathrm{O}_{4}$ are depicted in Figure 8. The initial decomposition temperatures $\left(T_{i}\right)$ of $\mathrm{N}_{3}$ PTMS- $g-\mathrm{Fe}_{3} \mathrm{O}_{4}$ and $\mathrm{POH}-$ $\mathrm{N}_{3}$ PTMS- $g-\mathrm{Fe}_{3} \mathrm{O}_{4}$ are respectively 226 and $217^{\circ} \mathrm{C}$. The decrease in thermal stability of POH-N ${ }_{3}$ PTMS- $g-\mathrm{Fe}_{3} \mathrm{O}_{4}$ related to $\mathrm{N}_{3} \mathrm{PTMS}-\mathrm{g}-\mathrm{Fe}_{3} \mathrm{O}_{4}$ is attributed to the formation of the 1,2,3-triazole ring. It can be observed that at $400{ }^{\circ} \mathrm{C}$, the $\%$ mass loss of $\mathrm{N}_{3} \mathrm{PTMS}-g-\mathrm{Fe}_{3} \mathrm{O}_{4}$ is $4.6 \%$ which is lower than $7.0 \%$ for POH-N ${ }_{3}$ PTMS- $g$ $\mathrm{Fe}_{3} \mathrm{O}_{4}$. The friction of mass loss inconsistent also with the formation of the triazole ring through click reaction. For different temperature readings, the percentage can also be determined. For instance, the residues percent at $800{ }^{\circ} \mathrm{C}$ are recorded as 92.4 and 88.5 , respectively. The reason for the higher mass loss (\%) at $400{ }^{\circ} \mathrm{C}$ and a lower $\%$ residue at $800{ }^{\circ} \mathrm{C}$ for $\mathrm{POH}-$ $\mathrm{N}_{3}$ PTMS- $g-\mathrm{Fe}_{3} \mathrm{O}_{4}$ is probably the click reaction. This is because click reaction increases the linearity of the $\mathrm{POH}-\mathrm{N}_{3} \mathrm{PTMS}-\mathrm{g}-\mathrm{Fe}_{3} \mathrm{O}_{4}$ which increases the free volume (decrease in $T_{g}$ ). The increase in free volume makes the POH-N ${ }_{3}$ PTMS- $g-\mathrm{Fe}_{3} \mathrm{O}_{4}$ susceptible to rapid $\%$ mass loss at $400{ }^{\circ} \mathrm{C}$.

Figure 9 depicts the DSC curves of 5, 10, and 20\% PVC- $g$-POH-N ${ }_{3}$ PTMS- $g-\mathrm{Fe}_{3} \mathrm{O}_{4}$ composites. When the amount of PVC increased from $5 \%$ to $10 \%$, the $T_{g}$ value increased from 60 to $72{ }^{\circ} \mathrm{C}$. This is because when the PVC percentage is used more than 5\%, the distance between the chains does not change much, i.e., when the ratio is exceeded $10 \%$, the distance between the chains decreases, and hence, decreases the free volume in the polymer. The $T_{g}$ value for $20 \%$ composite is 73 ${ }^{\circ} \mathrm{C}$ which was very close to that of $10 \%$ composite even though the $20 \%$ composite has POH-N ${ }_{3} \mathrm{PTMS}-g-\mathrm{Fe}_{3} \mathrm{O}_{4}$ contents as twice as the composite contains $10 \%$ PVC. In other words, the $\mathrm{POH}-\mathrm{N}_{3} \mathrm{PTMS}-g-\mathrm{Fe}_{3} \mathrm{O}_{4}$ added has not considerably affected their $T_{g}$ temperatures. A worth mentioning outcome from Table 2 is the increase in the $T_{g}$ temperature of the composites as the $\mathrm{POH}$ $\mathrm{N}_{3}$ PTMS- $g-\mathrm{Fe}_{3} \mathrm{O}_{4}$ percentage increases in each composite. This result implies that the presence of $\mathrm{POH}-\mathrm{N}_{3} \mathrm{PTMS}-g-\mathrm{Fe}_{3} \mathrm{O}_{4}$ within the PVC matrix decreases the free volume of the composite which leads to an increase in the glass transition temperature $\left(T_{g}\right)$ of the composite. TGA curves of 5, 10, and 20\% PVC/POH-N ${ }_{3}$ PTMS- $g-\mathrm{Fe}_{3} \mathrm{O}_{4}$ composites are shown in Figure 10. The initial decomposition temperatures $\left(T_{i}\right)$ of 5,10 , and $20 \%$ composites are respectively 203 , 210 , and $217^{\circ} \mathrm{C}$. It can be seen that there is an increase in the thermal stability of the composites due to the increase in POH-N $\mathrm{N}_{3} \mathrm{PTMS}-g-\mathrm{Fe}_{3} \mathrm{O}_{4}$ contents within the PVC matrix which is in line with the $T_{g}$ observed from the DSC curves. Also, the TGA curve at $300{ }^{\circ} \mathrm{C}$ shows that the $\%$ mass loss is 57 for the $5 \%$ composite. The $\%$ mass loss increases to 79 for the $10 \%$ composite, while this value for $20 \%$ composite reaches 44 . This implies that the rate of thermal decomposition of the composites is independent of the percentages of $\mathrm{POH}-$ $\mathrm{N}_{3}$ PTMS- $g-\mathrm{Fe}_{3} \mathrm{O}_{4}$ used in the composite preparation. For composites containing 5\%, 10\%, and 20\% PVC, the residue at $450{ }^{\circ} \mathrm{C}$ were observed to be $3.2,7.7$, and 11.4 , respectively. The observed residue is obviously as a result of the high amount of POH-N $\mathrm{N}_{3}$ PTMS- $g$ $\mathrm{Fe}_{3} \mathrm{O}_{4}$ in the $20 \%$ composite compared to $5 \%$ and $10 \%$ composites. 


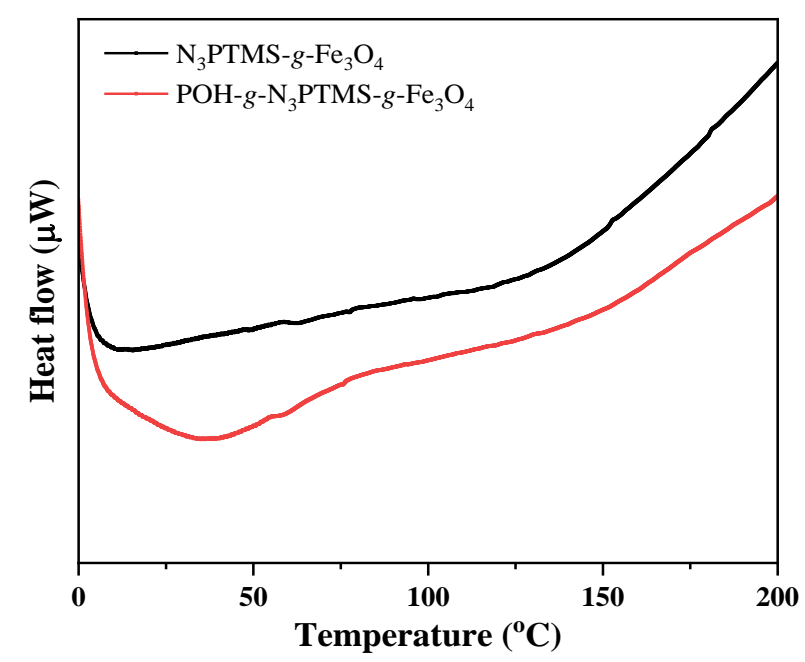

Figure 7. DSC curves of $\mathrm{N}_{3} \mathrm{PTMS}-g-\mathrm{Fe}_{3} \mathrm{O}_{4}$ and POH- $g$ $\mathrm{N}_{3}$ PTMS- $g-\mathrm{Fe}_{3} \mathrm{O}_{4}$

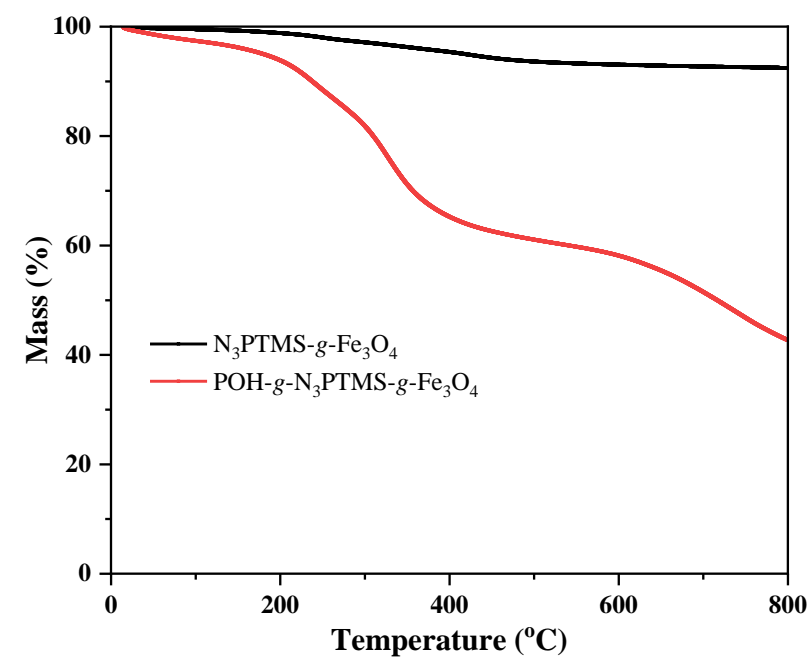

Figure 8. TGA curves of $\mathrm{N}_{3} \mathrm{PTMS}-g-\mathrm{Fe}_{3} \mathrm{O}_{4}$ and POH- $g$ $\mathrm{N}_{3}$ PTMS- $g-\mathrm{Fe}_{3} \mathrm{O}_{4}$

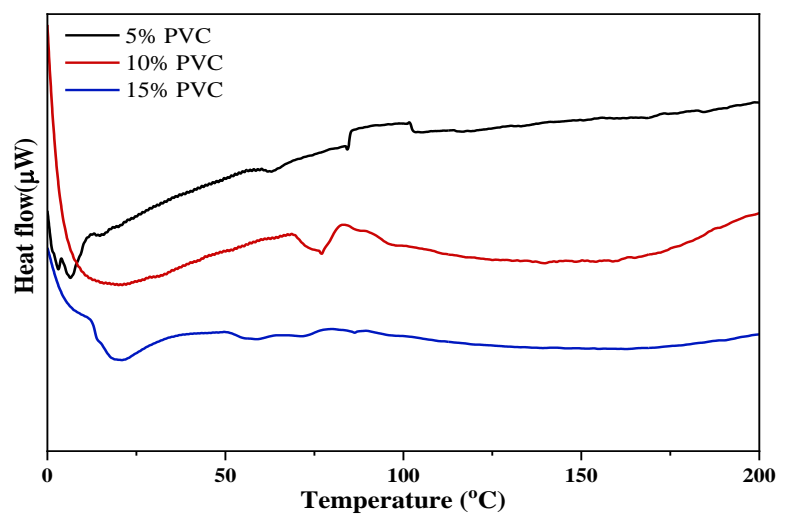

Figure 9. DSC curves of composites containing 5\% PVC, $10 \%$ PVC, and $20 \%$ PVC

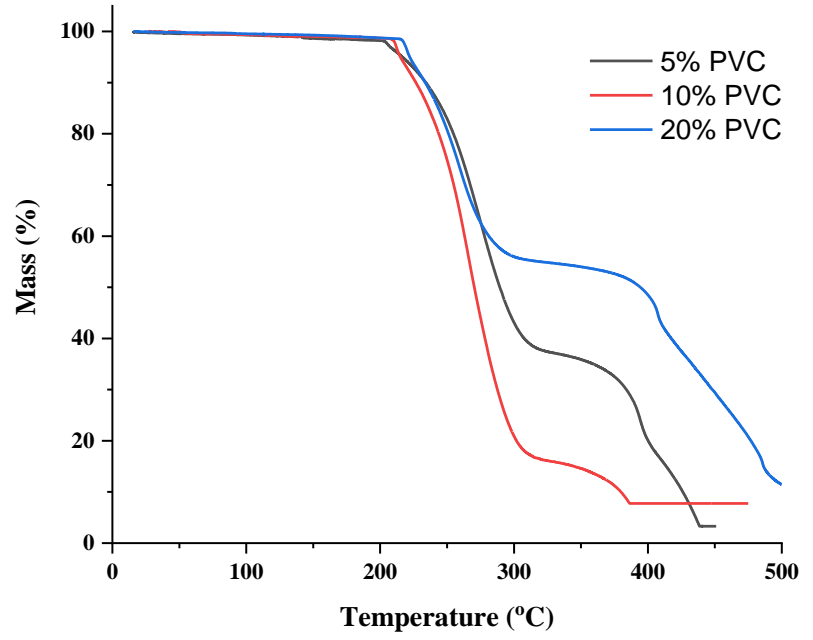

Figure 10. TGA curves of 5\%, 10\% and 20\% PVC- $g$-POH$\mathrm{N}_{3} \mathrm{PTMS}-\mathrm{g}-\mathrm{Fe}_{3} \mathrm{O}_{4}$ composites

Table 1. Thermal investigation of modified $\mathrm{Fe}_{3} \mathrm{O}_{4}$

\begin{tabular}{lllll}
\hline $\begin{array}{l}\text { Modified } \\
\mathrm{Fe}_{3} \mathrm{O}_{4}\end{array}$ & $\begin{array}{l}T_{g} \\
\left({ }^{\circ} \mathrm{C}\right)\end{array}$ & $\begin{array}{l}T_{i} \\
\left({ }^{\circ} \mathrm{C}\right)\end{array}$ & $\begin{array}{l}\% \text { Mass } \\
\text { Loss at } \\
400{ }^{\circ} \mathrm{C}\end{array}$ & $\begin{array}{l}\% \text { Residue } \\
\text { at } 800{ }^{\circ} \mathrm{C}\end{array}$ \\
\hline $\begin{array}{l}\mathrm{N}_{3} \mathrm{PTMS}-g- \\
\mathrm{Fe}_{3} \mathrm{O}_{4}\end{array}$ & 61 & 226 & 4.6 & 92.4 \\
$\begin{array}{l}\mathrm{POH}- \\
\mathrm{N}_{3} \mathrm{PTMS}-g-\end{array}$ & 57 & 217 & 35.0 & 43 \\
$\mathrm{Fe}_{3} \mathrm{O}_{4}$ & & & & \\
\hline
\end{tabular}

Table 2. Thermal investigation of PVC- $g$-POH- $g-\mathrm{N}_{3}$ PTMS$g-\mathrm{Fe}_{3} \mathrm{O}_{4}$ composites

\begin{tabular}{lcccc}
\hline Composites & $\begin{array}{c}T_{g} \\
\left({ }^{\circ} \mathrm{C}\right)\end{array}$ & $\begin{array}{c}T_{i} \\
\left({ }^{\circ} \mathrm{C}\right)\end{array}$ & $\begin{array}{c}\text { \% Mass } \\
\text { Loss at } \\
300{ }^{\circ} \mathrm{C}\end{array}$ & $\begin{array}{c}\text { \% Residue } \\
\text { at } 450{ }^{\circ} \mathrm{C}\end{array}$ \\
\hline $\begin{array}{l}5 \% \\
\text { composite }\end{array}$ & 60 & 203 & 57 & 3.2 \\
$\begin{array}{l}10 \% \\
\text { composite }\end{array}$ & 72 & 210 & 79 & 7.7 \\
$\begin{array}{l}20 \% \\
\text { composite }\end{array}$ & 73 & 217 & 44 & 28 \\
\hline
\end{tabular}

\subsection{Electrical investigation}

The concept of permeability, which is the ratio of dielectric permeability to vacuum permeability, refers to the ability of a material to be polarized. In order for the dielectric constant to be great, the polarization developed by the material in an applied field must be great. Some times, polar polymers need to align the dipoles. At very high frequencies, the dipoles do not have enough time to align before the field direction changes, but at low frequencies they have sufficient time. In the intermediate frequencies, although the dipoles move, they have completed their movements before the field direction changes [11]. Impedance analyzer is a well-known technique used for 
characterizing the dielectric properties of the $\mathrm{POH}-$ $\mathrm{N}_{3}$ PTMS- $g-\mathrm{Fe}_{3} \mathrm{O}_{4}$ and its 5, 10, and $20 \%$ composites. The dielectric constant $\left(\varepsilon^{\prime}\right)$, dielectric loss $\left(\varepsilon^{\prime \prime}\right)$ and AC conductivity $\left(\sigma_{a c}\right)$ are used to characterize the electrical response of a polymer, copolymer, and composite material. They were measured within the same frequency range at room temperature except for the $\varepsilon^{\prime \prime}$ of the composites. Even though mobilization of the dipoles rests on the softness of a material, the dipoles in a polymeric material display a trend to orient in the direction of an applied field [17]. For POH-N ${ }_{3}$ PTMS$g-\mathrm{Fe}_{3} \mathrm{O}_{4}, \varepsilon^{\prime}, \varepsilon^{\prime \prime}$, and $\sigma_{a c}$ are depicted in Figure 11 . The variation of dielectric constant $\left(\varepsilon^{\prime}\right)$ with frequency at room temperature is almost the same as that of dielectric loss $\left(\varepsilon^{\prime \prime}\right)$. At higher frequency, a rapid decrease was observed to a frequency of around 900 $\mathrm{Hz}$, very slowly to a frequency of $5000 \mathrm{~Hz}$, and then continue more or less constant. For the AC conductivity $\left(\sigma_{a c}\right)$ at a higher frequency, it increased rapidly to a frequency of $900 \mathrm{~Hz}$, the increment becomes very slow up to an approximate frequency of $5000 \mathrm{~Hz}$ and then continuous more or less linearly with an increase in applied frequency. The inset graphs in Figure 12a depicts the variation of $\varepsilon^{\prime}$ of composites with frequency at room temperature. From the graph, it was observed that the $\varepsilon^{\prime}$ of the composites increases with increasing POH-N ${ }_{3} \mathrm{PTMS}-g-\mathrm{Fe}_{3} \mathrm{O}_{4}$. The $\varepsilon^{\prime}$ values of 5, 10, and $20 \%$ composites are 2.2, 3.0, and 3.9 respectively compared to that of pure $\mathrm{POH}-\mathrm{N}_{3} \mathrm{PTMS}$ $g-\mathrm{Fe}_{3} \mathrm{O}_{4}$ which is 6.0. The main cause in this increase in composites $\varepsilon^{\prime}$ seems to be the sequential addition of POH-N ${ }_{3}$ PTMS- $g-\mathrm{Fe}_{3} \mathrm{O}_{4}$ into the composite. In this context, effective interaction depends on enhancing the compatibility between POH- ${ }_{3} \mathrm{PTMS}-g-\mathrm{Fe}_{3} \mathrm{O}_{4}$ and the PVC matrix through dispersion process which reduces the cohesive forces in the PVC chain leading to an increase in segmental mobility in the composite and hence, more dipoles are developed. The variation of dielectric loss of the composites (Figure 12b) shows an anomalous behavior as the applied frequency is increased at room temperature. Figure $12 \mathrm{c}$ demonstrates the variation of $\sigma_{a c}$ in composites as a function of frequency. The $\sigma_{a c}$ increases with increasing the applied frequency. Its also observed that the conductivity of the composite increases with an increase in the amount of POH- $g-\mathrm{N}_{3}$ PTMS- $g-\mathrm{Fe}_{3} \mathrm{O}_{4}$ within the composite.
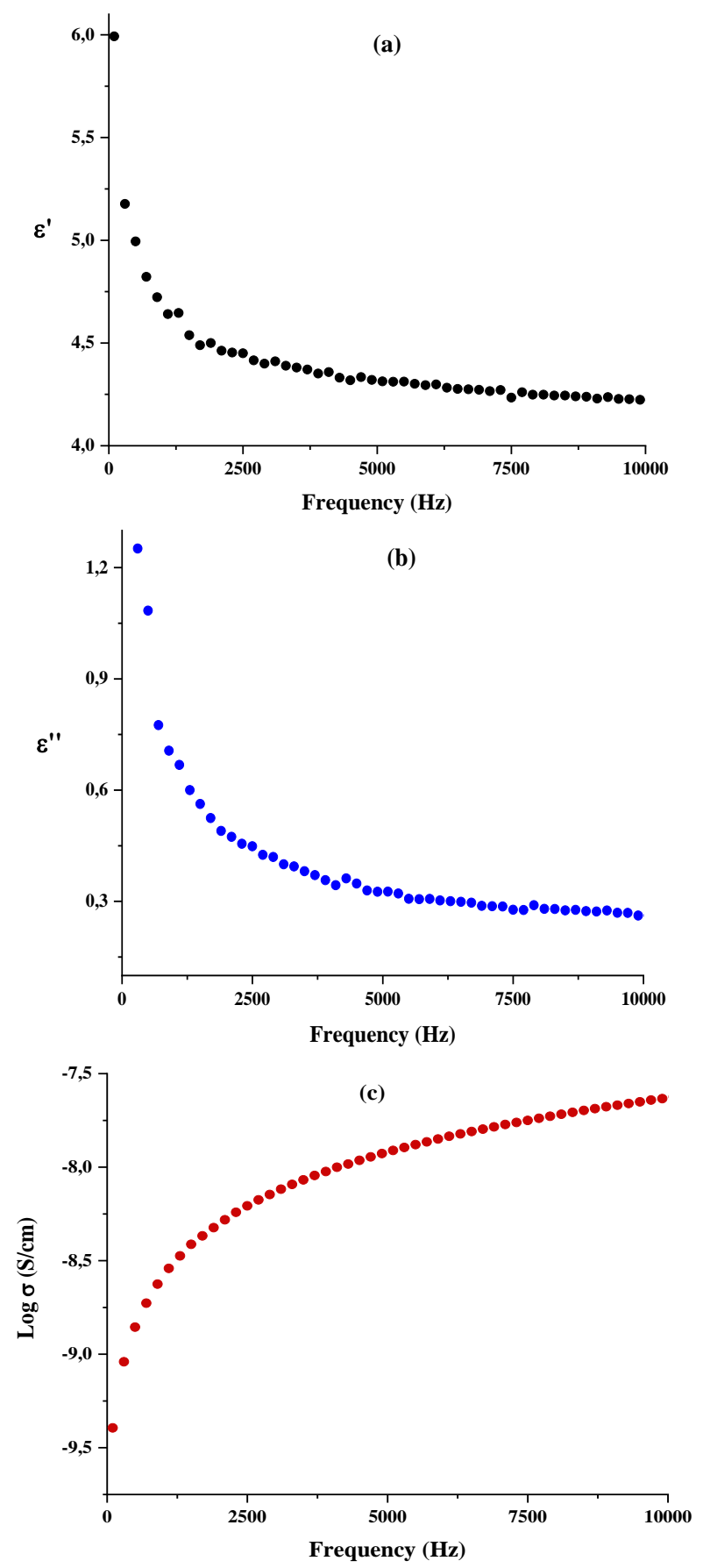

Figure 11. Variation of (a) dielectric constant (b) dielectric loss and (c) AC conductivity of POH-N ${ }_{3} \mathrm{PTMS}-g-\mathrm{Fe}_{3} \mathrm{O}_{4}$ with frequency at room temperature. 

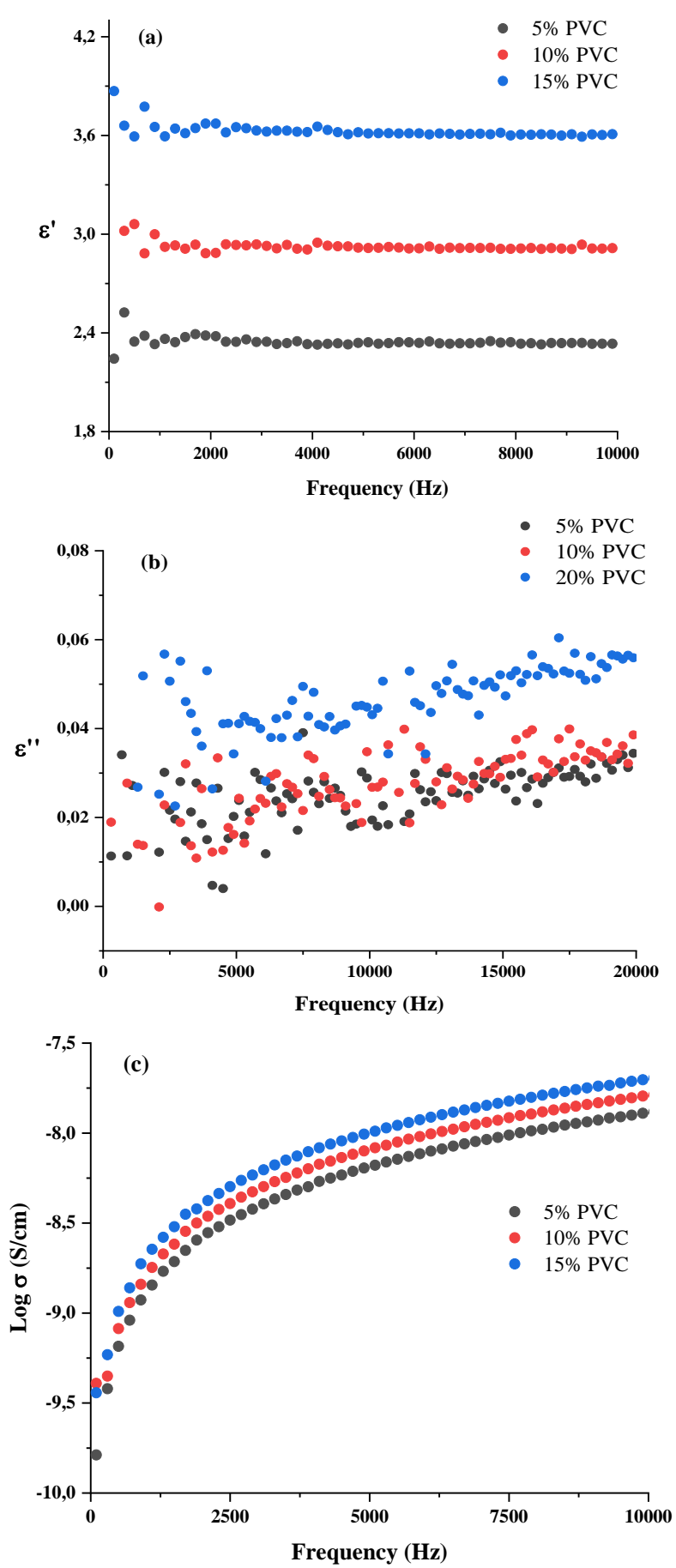

Figure 12. Variation of (a) dielectric constant (b) dielectric loss and (c) AC conductivity of PVC/POH-N ${ }_{3}$ PTMS- $g$ $\mathrm{Fe}_{3} \mathrm{O}_{4}$ composites with frequency at room temperature.

\section{Conclusions}

The effect on the structure, thermal, and dielectric properties of $\mathrm{POH}-\mathrm{N}_{3} \mathrm{PTMS}-\mathrm{g}-\mathrm{Fe}_{3} \mathrm{O}_{4}$ obtained by click reaction on 5, 10, and 20\% PVC composites were investigated. FT-IR spectroscopy and SEM-EDX techniques were used in the characterization process. The saturation magnetization value $\left(M_{s}\right)$ of the composite was calculated as $5.12 \mathrm{emu} / \mathrm{g}$ from the magnetization curve. Thermal analysis of $\mathrm{N}_{3}$ PTMS- $g$ -
$\mathrm{Fe}_{3} \mathrm{O}_{4}, \mathrm{POH}-\mathrm{N}_{3} \mathrm{PTMS}-\mathrm{g}-\mathrm{Fe}_{3} \mathrm{O}_{4}$, and the PVC/POH$\mathrm{N}_{3}$ PTMS- $g-\mathrm{Fe}_{3} \mathrm{O}_{4}$ composites were carried out to investigate the influence of the amount $\mathrm{POH}-\mathrm{N}_{3}$ PTMS$g-\mathrm{Fe}_{3} \mathrm{O}_{4}$ on the thermal behavior of the composites. It was observed that the glass transition temperature $\left(T_{g}\right)$ value of $\mathrm{N}_{3}$ PTMS- $g-\mathrm{Fe}_{3} \mathrm{O}_{4}$ is higher than that of POH$\mathrm{N}_{3}$ PTMS- $g-\mathrm{Fe}_{3} \mathrm{O}_{4}$ due to the formation of the 1,2,3triazole ring. Likewise, the $T_{g}$ of the composites increases as the amount of POH-N $\mathrm{N}_{3}$ PTMS- $g-\mathrm{Fe}_{3} \mathrm{O}_{4}$ is increased. The result implies that the presence of $\mathrm{POH}-$ $\mathrm{N}_{3}$ PTMS- $g-\mathrm{Fe}_{3} \mathrm{O}_{4}$ within the PVC matrix decreases the free volume, and thus, the $T_{g}$ of the composites increases. Initial decomposition temperature $\left(T_{i}\right)$ was found to be $226{ }^{\circ} \mathrm{C}$ and $217{ }^{\circ} \mathrm{C}$ for $\mathrm{N}_{3} \mathrm{PTMS}-g-\mathrm{Fe}_{3} \mathrm{O}_{4}$ and $\mathrm{POH}-\mathrm{N}_{3} \mathrm{PTMS}-\mathrm{g}-\mathrm{Fe}_{3} \mathrm{O}_{4}$ respectively. For the composites, it was observed that the thermal stability of the composites increases with increasing the friction of $\mathrm{POH}-\mathrm{N}_{3} \mathrm{PTMS}-\mathrm{g}-\mathrm{Fe}_{3} \mathrm{O}_{4}$. Initial decomposition temperature $\left(T_{i}\right)$ were $203{ }^{\circ} \mathrm{C}$ for $5 \%, 210{ }^{\circ} \mathrm{C}$ for $10 \%$, and $217{ }^{\circ} \mathrm{C}$ for $20 \%$ PVC- $g$-POH-N ${ }_{3}$ PTMS- $g-\mathrm{Fe}_{3} \mathrm{O}_{4}$ composites. An increase in the thermal stability of the composites was due to the increase in the amount of POH-N ${ }_{3}$ PTMS- $g-\mathrm{Fe}_{3} \mathrm{O}_{4}$ within the PVC matrix, and hence, it conform the $T_{g}$ results observed from the DSC curves. Also, the residue of $\mathrm{N}_{3} \mathrm{PTMS}-\mathrm{g}-\mathrm{Fe}_{3} \mathrm{O}_{4}$ was 92.4\% in Table 1, while the residue of POH- $\mathrm{N}_{3} \mathrm{PTMS}-$ $g$ - $\mathrm{Fe}_{3} \mathrm{O}_{4}$ due to the decomposition of both $\mathrm{N}_{3} \mathrm{PTMS}$ and $\mathrm{POH}$ organic groups in the structure was found to be $43 \%$. The dielectric constant $\left(\varepsilon^{\prime}\right)$ and dielectric loss factor $\left(\varepsilon\right.$ ") for POH-N 3 PTMS- $g$ - $\mathrm{Fe}_{3} \mathrm{O}_{4}$ decreased with an increase in applied frequency and for the AC conductivity $(\sigma)$, it increased rapidly with an increase in applied frequency. For the composites prepared, it was observed that the dielectric constant, dielectric loss factor, and $\mathrm{AC}$ conductivity increased as the $\mathrm{POH}$ $\mathrm{N}_{3}$ PTMS- $g-\mathrm{Fe}_{3} \mathrm{O}_{4}$ percentage increased within the PVC matrix. The $\varepsilon^{\prime}$ values of 5,10 , and $20 \%$ composites were 2.2, 3.0, and 3.9 respectively.

\section{Acknowledgment}

The authors would like to thank the Firat University Scientific Research Projects Coordination Unit (FÜBAP) for the financial support of this research, Elazig, Turkey, project number FF.18.18.

\section{Conflicts of interest}

The authors state that did not have conflict of interests

\section{References}

[1] Wilson J., Poddar P., Frey N., Srikanth H., Mohomed K., Harmon J., Kotha S. and Wachsmuth J. Synthesis and magnetic properties of polymer nanocomposites with embedded iron 
nanoparticles. Journal of Applied Physics, 95 (2004) 1439-1443.

[2] Frounchi M., Hadi M. Effect of synthesis method on magnetic and thermal properties of polyvinylidene fluoride/Fe3O4 nanocomposites. Journal of Reinforced Plastics and Composites, 32 (2013) 1044-1051.

[3] Omidi M. H., Alibeygi M., Piri F. and Masoudifarid M. Polystyrene/magnetite nanocomposite synthesis and characterization: investigation of magnetic and electrical properties for using as microelectromechanical systems (MEMS). Materials Science-Poland, 35 (2017) 105-110.

[4] Chávez-Guajardo A. E., Medina-Llamas J. C., Maqueira L., Andrade C. A., Alves K. G. and de Melo C. P. Efficient removal of $\mathrm{Cr}$ (VI) and $\mathrm{Cu}$ (II) ions from aqueous media by use of polypyrrole/maghemite and polyaniline/maghemite magnetic nanocomposites. Chemical Engineering Journal, 281 (2015) 826836.

[5] Haruna H., Pekdemir M. E., Tukur A. and Coşkun M. Characterization, thermal and electrical properties of aminated PVC/oxidized MWCNT composites doped with nanographite. Journal of Thermal Analysis and Calorimetry, (2020) 1-9.

[6] Qiu F., He G., Hao M. and Zhang G. Enhancing the Mechanical and Electrical Properties of Poly (Vinyl Chloride)-Based Conductive Nanocomposites by Zinc Oxide Nanorods. Materials, 11 (2018) 2139.

[7] Tao Y., Feng W., Ding G. and Cheng G. Polyaniline nanorods/PVC composites with antistatic properties. Russian Journal of Physical Chemistry A, 89 (2015) 1445-1448.

[8] Habashy M. M., Abd-Elhady A. M., Elsad R. and Izzularab M. A. Performance of $\mathrm{PVC} / \mathrm{SiO} 2$ nanocomposites under thermal ageing. Applied Nanoscience, (2019) 1-9.

[9] Yazdani H., Hatami K., Khosravi E., Harper K. and Grady B. P. Strain-sensitive conductivity of carbon black-filled PVC composites subjected to cyclic loading. Carbon, 79 (2014) 393-405.
[10] Yao K., Gong J., Tian N., Lin Y., Wen X., Jiang Z., Na H. and Tang T. Flammability properties and electromagnetic interference shielding of PVC/graphene composites containing $\mathrm{Fe} 3$ O 4 nanoparticles. Rsc Advances, 5 (2015) 3191031919.

[11] Tukur A., Pekdemir M. E., Haruna H. and Coşkun M. Magnetic nanoparticle bonding to PVC with the help of click reaction: characterization, thermal and electrical investigation. Journal of Polymer Research, 27 (2020) 161.

[12] Ramesan M., Privya P., Jayakrishnan P., Kalaprasad G., Bahuleyan B. and Al-Maghrabi M. Influence of magnetite nanoparticles on electrical, magnetic and thermal properties of chitin/cashew gum biopolymer nanocomposites. Polymer Composites, 39 (2018) E540-E549.

[13] Kirchberg S., Rudolph M., Ziegmann G. and Peuker U. Nanocomposites based on technical polymers and sterically functionalized soft magnetic magnetite nanoparticles: synthesis, processing, and characterization. Journal of Nanomaterials, 2012 (2012).

[14] Namanga J., Foba J., Ndinteh D. T., Yufanyi D. M. and Krause R. W. M. Synthesis and magnetic properties of a superparamagnetic nanocomposite "pectin-magnetite nanocomposite". Journal of Nanomaterials, 2013 (2013).

[15] Aliabadi M., Shagholani H. Synthesis of a novel biocompatible nanocomposite of graphene oxide and magnetic nanoparticles for drug delivery. International journal of biological macromolecules, 98 (2017) 287-291.

[16] Singh R., Puri J. K., Sharma R. P., Malik A. K. and Ferretti V. Synthesis, characterization and structural aspects of 3-azidopropylsilatrane. Journal of Molecular Structure, 982 (2010) 107112.

[17] González-Guisasola C., Ribes-Greus A. Dielectric relaxations and conductivity of cross-linked PVA/SSA/GO composite membranes for fuel cells. Polymer Testing, 67 (2018) 55-67.. 